\title{
DISTRIBUTION OF EXPECTED TIME OF OLD-AGE PENSION RECEIPT IN CZECHIA*
}

\section{Tomáš Fialaa iD, Jitka Langhamrováa iD}

\begin{abstract}
This paper presents a calculation of the estimated value of the time of old age pension receipt for individual birth cohorts of Czech males and females born in the period 1900-2020. It is assumed that people start to receive the pension at the moment of reaching retirement age and receive it until death. Starting with the birth cohort of 1966, two variants of retirement age determination are assumed: (a) a fixed retirement age threshold equal to 65 years for both males and females; and (b) a flexible retirement age (equal for males and females) defined in such a way that the average time of pension receipt would be equal to one quarter of the total expected total life span of people reaching senior age. The average lengths of pension receipt as well as the structure of adult persons from each birth cohort according to five-year time intervals of pension receipt (including the proportion of adult persons not surviving until retirement age) in the future are presented. Cohort life tables were used for calculations.
\end{abstract}

Keywords: Retirement age, cohort life tables, birth cohorts, lengths of pension receipt, Czechia

JEL Classification: J11, J14, J26

\section{Introduction}

Population ageing is one of the most important and most frequently discussed demographic phenomena of the current century (e.g., Gavrilov and Heuveline, 2003). Almost all economically developed countries face the consequences of demographic ageing at present and less developed countries will probably be affected by ageing in the nearest decades.

The main reason for population ageing is not only the permanent increase in life expectancy (which is expected to continue throughout the following decades) but also

* This article was supported by Czech Science Foundation grant no. GA ČR 19-03984S under the title "Economy of Successful Ageing".

a Prague University of Economics and Business, Faculty of Informatics and Statistics, Department of Demography, Prague, Czech Republic

Email: fiala@vse.cz; langhamj@vse.cz 
the decrease in fertility of females, in many countries below the replacement level. In some countries or regions, the third, not so often mentioned, cause of ageing is massive emigration of young adult people at reproductive age.

Population ageing is often considered a serious threat to the financial sustainability of welfare systems (mainly of the pension and health care systems). Almost all such concerns are based on the assumption that the old age threshold is constant (usually equal to 65 years of age, which is the value of retirement age in many countries), although there arises the natural idea that if the length of human life has been increasing for several decades then the old age threshold should increase too.

A proposal for a re-examination of the concept of a fixed old age threshold was published already in 1975 by Ryder. He suggested the idea to consider the point of entry into old age as the value of age at which the remaining life expectancy is equal to a given, relatively low, value, say, 10 years (Ryder, 1975).

Ryder's concept was at first mentioned relatively rarely because population ageing was not yet considered a serious threat in the 1970s. The idea of a flexible old age threshold, depending on the remaining life expectancy, was also suggested by Fuchs (1984) about ten years later. Siegel (1993) proposed the idea of an old-age threshold as the age when the life expectancy equals to 15 years.

The idea of a new concept of human age and new indicators of old age based on a forward-looking conception was detailed by Sanderson and Scherbov in several papers. They introduced a new forward-looking definition of age and argued that, along with the traditional backward-looking concept of age, this definition provides a more informative basis for discussing population ageing (Sanderson and Scherbov, 2005). Their concept of age determination is based on expected years of remaining life (remaining life expectancy) instead of number of years lived (biological age). The indicators of ageing based on such a concept show that the increase in many indicators of ageing in such a case will not be so dramatic in comparison with indicators defined in the standard way (Sanderson and Scherbov, 2010, 2013). A comparison of standard and prospective indicators of ageing for the $28 \mathrm{EU}$ countries is presented, e.g., by Šídlo et al. (2020).

Population ageing is considered a threat to the financial sustainability of pension systems. In many countries the pension age is fixed, often equal to 65 years of age. In such a case an increase in life expectancy results in prolonging the average time of pension receipt and so increasing the proportion of pensioners in the population. One of the main measures in most pension reforms is the idea of increasing retirement age, often above the usual threshold of 65 years.

In Czechia, the retirement age threshold in the second half of the previous century was relatively low. For males it was 60 (with a lower threshold for several special professions - 
pilots, miners, etc.). The retirement age for females was 55 and later differentiated by the number of their children from 53 ( 5 or more children) to 57 (childless). Females with 2 children (which was the most frequent case) had an unchanged retirement age of 55 (Fiala and Langhamrová, 2015b). Despite the constant value of the retirement age threshold, the value of the adjusted old-age dependency ratio was relatively stable in the 1970s, 1980s and early 1990s. The main reason was the fact that the numerous generations of seniors born before the First World War were gradually dying, while at the same time, numerous cohorts born after the Second World War were reaching productive age. Moreover, life expectancy remained almost unchanged during this period (Arltová et al., 2013).

After 1990 there emerged the idea that the retirement age in Czechia should increase to the level usual in most European countries (65 years), and the threshold for males and females should be unified. According to the new legal arrangement of the pension system (Act no. 155/1995 Coll.), the retirement age in Czechia started to rise from 1996 by 2 months for males and 4 months for females for each subsequent birth cohort. The period of this increase was prolonged several times. One of the latest amendments (Act No. 220/2011 Coll.) prolonged the increase of retirement age permanently without any upper limit, e.g., persons born in 2013 should retire at 73, persons born in 2025 should retire at 75 , etc. At the same, time the increase in retirement age for females was accelerated to 6 months for each subsequent birth cohort to reach the threshold of males sooner.

The idea of such a permanent increase in retirement age, regardless of the development of life expectancy, was often criticized by some politicians. They argued that theoretically, if the increase in life expectancy slowed down or stopped, many people would not even reach retirement age or would receive a pension only for a relatively short time. One of the topics dealt with by the Expert Committee on Pension Reform of the Czech Republic in 2014 was the adjustment of the age limit for retirement in Czechia. The Expert Committee on Pension Reform approved the recommendation that the retirement age (which should be the same for both men and women) should continue to depend on the individual's year of birth. For the generations born before 1966, the retirement age should be in accordance with the previous legislation, supposing an increase (in comparison with the preceding births cohorts) by 2 months for men, by 4 months for women and by 6 months starting in 2019 until they reach the level of men. Men born in 1965 should thus retire in 2030 at the age of 65 , and women (born in the same year) with 2 children should retire at the age of 64 years and 8 months.

The value of the retirement age for persons born in 1966 and later was recommended to be determined in such a way that people reaching senior age should receive an old-age pension on average for the last quarter of their lives (Expert Committee, 2015). 
However, the final version of the law concerning old age pension passed by the Czech Parliament aims to stop the retirement age increase at the level of 65 years after 2030. The calculations of the retirement age, which would lead to receiving an old-age pension on average for the last quarter of one's life, would be carried out regularly every five years, but they would serve only as information for the government (Act no. 203/2017 Coll.). The first such type of calculations based on the population projection of the Czech Republic for 2018-2100 (CZSO, 2018a) showed that the retirement age increase should continue. Nevertheless, the minister of labour and social affairs did not submit any proposal to increase the retirement age and so it will be proposed probably as late as in 2024 after updated calculations are carried out. Throughout this paper, pension will be taken to mean the lifelong old-age pension paid out from the moment of attaining retirement age until death (unless expressly stated otherwise). The increase in retirement age as well as the decrease in mortality have of course affected the lengths of time of pension receipt. A simple estimate of this time often used is the value of remaining life expectancy at the retirement age. However, its value characterizes only the average value of the time of pension receipt and, in the case of life expectancy from period life tables (which are more readily available than cohort ones), it underestimates real pension receipt time because period life tables do not assume the decrease in mortality that is expected in future.

This paper presents a calculation of the estimated value of the time of old age pension receipt for individual cohorts of Czech males and females born in the period 1900-2020. The methodology of construction of cohort life tables for Czechia and of the calculation of the distribution of the time of pension receipt are described in Section 1. Starting with the birth cohort of 1966, two variants of retirement age determination are assumed:

(a) a fixed retirement age threshold equal to 65 years for both males and females (in accordance with current legislation); and

(b) a flexible retirement age (also the same for males and females) defined in such a way that the average time of pension receipt would be equal to one quarter of the expected total life span of people reaching senior age (recommendation of future changes of pension age).

The average lengths of pension receipt as well as the structure of adult persons from each birth cohort according to expected time of pension receipt (including the proportion of adult persons who do not survive until pension age) in the future are presented.

The main goal of the analysis is to show how the present increase in retirement age, as well as the proposed increase in the future, will affect the time of pension receipt and what the future amount of the time of pension receipt would be if the increase in pension age were stopped at the age of 65 from 2030. 


\section{Calculation of Cohort Life Tables and Time of Pension Receipt}

The life tables usually published are period tables. It means that they characterize the level of mortality in individual age groups during one year or a relatively short time interval. The biometrical measures presented in these tables characterize the level of mortality in the short period from which the initial data came. Using these values (especially life expectancy) for estimation of future development means making a prediction under the assumption that the level of mortality in future years will be the same as in the year(s) of the tables. For example, the value of life expectancy gives the average value of remaining life of a person at a given age under the assumption that in future years mortality in all ages will be the same as in the year(s) of the tables, i.e., that there will be no future decrease (but also no increase) in age-specific mortality rates.

After a period of relative stagnation (and for males even a short time of increase) of mortality rates in Czechia in the 1960s, 1970s and early 1980s, mortality rates started to decrease relatively rapidly from 1990. Although the year-on-year decrease in mortality diminished slightly in recent years, all demographic projections suppose (in all variants) a continual increase in life expectancy until the end of this century (Pechholdová, 2019). Thus, for an estimation of the remaining life span of (not only) the Czech population, cohort life tables and cohort life expectancies should be used. These tables characterize the mortality not of the entire population in a short time period but the mortality of a selected birth cohort of persons during their life. Of course, life tables of cohorts of persons who are still alive must be based not only on the mortality data during their life thus far, but also on some estimates of their mortality in the future. Cohort life tables can be calculated using several methods. We used an estimate based on (real or forecast) time series of period life tables. A person born in the year $g$ will reach the exact age of $x$ in the year $g+x$ and will therefore live at the completed age $x$ partly in the year $g+x$ (from his/her $x^{\text {th }}$ birthday until the end of the year), partly in the year $g+x+1$ (from the beginning of the year until the last day before his/her $(x+1)^{\text {st }}$ birthday). As an estimate of the probability of deaths at the age of $x$ for the cohort born in the year $g$, we can use the mean of the probabilities of deaths in the life tables for the years $x+g$ and $x+g+1$, respectively

$$
q_{x}^{(g)}=\frac{q_{g+x, x}+q_{g+x+1, x}}{2}
$$

where

$q_{x}^{(g)}$ denotes the cohort probability of death at the age $x$ for the birth cohort $g$,

$q_{t, x}$ denotes the period probability of deaths at the age $x$ in the year $t$. 
The calculation of the next biometrical measures of cohort life tables for the birth cohort $g$, $l_{x}^{(g)}-$ number of survivors to age $x$, $d_{x}^{(g)}$ - number of people who die at complete age $x$, $e_{x}^{(e)}$ - (remaining) life expectancy of people at exact age $x$,

is based on the cohort probabilities of death mentioned above and standard known formulas for life table computations.

The source of the period probabilities of death for individual years of the period 1920-2018 were the time series of life tables for Czechia published by the Czech Statistical Office (CZSO, 2019a). These tables were calculated retrospectively using the new methodology used by the CZSO since 2018 (CZSO, 2019b). The mortality rates were smoothed using the generalised additive model (the GAM method) combined with so-called P-splines; this method is sometimes called the P-GAM method (Eilers and Marx, 1996). The Kannisto model (Thatcher et al., 1998) was used for smoothing the mortality curves at the highest ages. This model is also frequently used in many other countries (Burcin et al., 2010) and in the Human Mortality Database project ${ }^{1}$. Using other models of mortality smoothing in old ages would cause only very slight differences (Burcin et al., 2010).

Probabilities of death for the future period 2019-2100 were estimated using the results of the projection of the population of the Czech Republic - the zero migration variant (CZSO, 2018a).

The mortality scenario of this projection used the Lee-Carter model (Lee and Carter, 1992; Lee, 2000). Mortality after 2100 is assumed to be unchanged; probabilities of death from the year 2101 are predicted to be equal to corresponding values of the year 2100 .

Utilizing the standard known formulas of population projection calculated by the component method, we can calculate for each year $t$ of the projection the life table numbers of person-years $L_{t, x}$

$$
\begin{aligned}
& L_{t, 0}=l_{0} \times \frac{S_{t+1,0}}{N_{t}}, \\
& L_{t, x+1}=L_{t, x} \times \frac{S_{t+1, x+1}}{S_{t, x}},
\end{aligned}
$$

where

$l_{0}$ is the life table radix, $N_{t}$ denotes the (projected) number of live births in the year $t$,

$S_{t, x}$ is the (projected) number of persons at complete age $x$ as of $1^{\text {st }}$ January of the year $t$.

1 www.mortality.org 
The calculation of table numbers of survivors and death probabilities was based on standard known formulas for life table computations. The calculations of cohort life tables were carried out separately for males and females. Fluctuations in values of calculated probabilities of death (caused by the fact that the projected numbers of live births and projected numbers of persons were rounded to integer values) were smoothed using the moving average method.

It seems to be reasonable to analyse the probability of surviving until retirement age and the distribution of the time of pension receipt only for adult persons in order to eliminate the influence of mortality at a younger age, especially infant mortality. At present, the usual upper threshold of economic active age is more often 20 years (instead of the 15 years used in the past). We thus compute the distribution of the time of pension receipt not for births cohorts, but for (hypothetical) cohorts of persons reaching the age of 20. (In the following text we shall use the term "adult" for persons of this age.) However, we shall mark each cohort by their year of birth (not by the year of reaching the age of 20).

The proportion of adult persons of a birth cohort not surviving until retirement age (and so receiving no pension) with respect to the cohort size at the age of 20 can be estimated using the number of survivors from corresponding cohort life tables,

$$
p_{-}^{(g)}=1-\frac{l_{r}^{(g)}}{l_{20}^{(g)}},
$$

where $r$ denotes the retirement age of the cohort. For a non-integer value of retirement age (which is a relatively frequent case in Czechia for males born after 1935 and females born after 1940), we use a linear interpolation formula

$$
p_{-}^{(g)}=1-\frac{(1-\alpha) \times l_{[r]}^{(g)}+\alpha \times l_{[r]+1}^{(g)}}{l_{20}^{(g)}},
$$

where

$[r]$ denotes the integer part of the value $r$ of retirement age, $\alpha=r-[r]$ is the fraction part.

The proportion of persons of a birth cohort surviving $x$ complete years after reaching retirement age (and so receiving a pension for $x$ years but less than $x+1$ years) with respect to the cohort size at the age of 20 can again be estimated using the number of dead persons from corresponding cohort life tables

$$
p_{x}^{(g)}=\frac{d_{r+x}^{(g)}}{l_{20}^{(g)}},
$$


for integer values of retirement age. In the case of a non-integer value, the linear interpolation formula has to be used

$$
p_{x}^{(g)}=\frac{(1-\alpha) \times d_{[r]+x}^{(g)}+\alpha \times d_{[r]+1+x}^{(g)}}{l_{20}^{(g)}} .
$$

\section{Retirement Age in Czechia}

From 1948, the retirement age for males in former Czechoslovakia and later in Czechia was 60 . The threshold of the retirement age for females was 55, later differentiated by the number of children reared, from 53 ( 5 or more children) to 57 (childless females). The retirement age for females with 2 children (the most frequent case) remained 55 (Fiala and Langhamrová, 2015b). For simplicity, we assume that all females have 2 children. These thresholds did not change until 1995. In this year the retirement age was reached by the cohorts of males born in 1935 and of females born in 1940 .

From 1996, the retirement age started to increase continually by 2 months for each subsequent birth cohort of males and by 4 months for females (in order to eliminate the gender difference in retirement age). For example, males born in 1936 retired at 60 years and 2 months, for males born in 1937 it was 60 years and 4 months, etc. Females born in 1941 retired at 55 years and 4 months, females born in 1942 retired at the age of 55 years and 8 months, etc. Since 2019, the increase in the retirement age of females has been 6 months for each subsequent birth cohort to reach the level of males by the early 2030s (Act no. 155/1995 Coll.).

Males born in 1965 will retire at 65 (which is the usual retirement age in many European countries at present), i.e., in the year 2030, while the retirement age for females (with two children) of the same birth cohort will be 64 years and 8 months. The retirement age threshold for persons born in 1966 or later should be (according to current legislation still in force) 65 years of age (except for females with 3 or more children, who will reach this threshold several years later). See Table 1 .

The assumed continuing increase in life expectancy in Czechia will result in an increase in the proportion of pensioners and at the same time the proportion of the labour force will decrease due to low fertility. One of the main measures in most pension reforms is the idea of a further increase in retirement age. The Council of the European Union recommends the Czech Republic to "ensure the long-term sustainability of the public pension scheme, in particular by accelerating the increase of the statutory retirement age and then by linking it more clearly to changes in life expectancy" (European Council, 2014, p. 15). The adjustment of the age limit for retirement in Czechia was one of the most important topics discussed by the Expert Committee on Pension Reform of the Czech Republic in 2014. 
Table 1: Retirement age in Czechia (current legislation)

\begin{tabular}{|c|c|c|c|c|c|c|}
\hline \multirow{2}{*}{$\begin{array}{l}\text { Year } \\
\text { of birth }\end{array}$} & \multirow[b]{2}{*}{ Males } & \multicolumn{5}{|c|}{ Females } \\
\hline & & 0 children & 1 child & 2 children & 3-4 children & $\begin{array}{l}5 \text { or more } \\
\text { children }\end{array}$ \\
\hline-1935 & $60 y$ & $57 y$ & $56 y$ & $55 y$ & $54 y$ & $53 y$ \\
\hline 1936 & $60 y+2 m$ & $57 y$ & $56 y$ & $55 y$ & $54 y$ & $53 y$ \\
\hline 1937 & $60 y+4 m$ & $57 y$ & $56 y$ & $55 y$ & $54 y$ & $53 y$ \\
\hline 1938 & $60 y+6 m$ & $57 y$ & $56 y$ & $55 y$ & $54 y$ & $53 y$ \\
\hline 1939 & $60 y+8 m$ & $57 y+4 m$ & $56 y$ & $55 y$ & $54 y$ & $53 y$ \\
\hline 1940 & $60 y+10 m$ & $57 y+8 m$ & $56 y+4 m$ & $55 y$ & $54 y$ & $53 y$ \\
\hline 1941 & $61 y$ & $58 y$ & $56 y+8 m$ & $55 y+4 m$ & $54 y$ & $53 y$ \\
\hline 1942 & $61 y+2 m$ & $58 y+4 m$ & $57 y$ & $55 y+8 m$ & $54 y+4 m$ & $53 y$ \\
\hline 1943 & $61 y+4 m$ & $58 y+8 m$ & $57 y+4 m$ & $56 y$ & $54 y+8 m$ & $53 y+4 m$ \\
\hline 1944 & $61 y+6 m$ & $59 y$ & $57 y+8 m$ & $56 y+4 m$ & $55 y$ & $53 y+8 m$ \\
\hline 1945 & $61 y+8 m$ & $59 y+4 m$ & $58 y$ & $56 y+8 m$ & $55 y+4 m$ & $54 y$ \\
\hline 1946 & $61 y+10 m$ & $59 y+8 m$ & $58 y+4 m$ & $57 y$ & $55 y+8 m$ & $54 y+4 m$ \\
\hline 1947 & $62 y$ & $60 y$ & $58 y+8 m$ & $57 y+4 m$ & $56 y$ & $54 y+8 m$ \\
\hline 1948 & $62 y+2 m$ & $60 y+4 m$ & $59 y$ & $57 y+8 m$ & $56 y+4 m$ & $55 y$ \\
\hline 1949 & $62 y+4 m$ & $60 y+8 m$ & $59 y+4 m$ & $58 y$ & $56 y+8 m$ & $55 y+4 m$ \\
\hline 1950 & $62 y+6 m$ & $61 y$ & $59 y+8 m$ & $58 y+4 m$ & $57 y$ & $55 y+8 m$ \\
\hline 1951 & $62 y+8 m$ & $61 y+4 m$ & $60 y$ & $58 y+8 m$ & $57 y+4 m$ & $56 y$ \\
\hline 1952 & $62 y+10 m$ & $61 y+8 m$ & $60 y+4 m$ & $59 y$ & $57 y+8 m$ & $56 y+4 m$ \\
\hline 1953 & $63 y$ & $62 y$ & $60 y+8 m$ & $59 y+4 m$ & $58 y$ & $56 y+8 m$ \\
\hline 1954 & $63 y+2 m$ & $62 y+4 m$ & $61 y$ & $59 y+8 m$ & $58 y+4 m$ & $57 y$ \\
\hline 1955 & $63 y+4 m$ & $62 y+8 m$ & $61 y+4 m$ & $60 y$ & $58 y+8 m$ & $57 y+4 m$ \\
\hline 1956 & $63 y+6 m$ & $63 y+2 m$ & $61 y+8 m$ & $60 y+4 m$ & $59 y$ & $57 y+8 m$ \\
\hline 1957 & $63 y+8 m$ & $63 y+8 m$ & $62 y+2 m$ & $60 y+8 m$ & $59 y+4 m$ & $58 y$ \\
\hline 1958 & $63 y+10 m$ & $63 y+10 m$ & $62 y+8 m$ & $61 y+2 m$ & $59 y+8 m$ & $58 y+4 m$ \\
\hline 1959 & $64 y$ & $64 y$ & $63 y+2 m$ & $61 y+8 m$ & $60 y+2 m$ & $58 y+8 m$ \\
\hline 1960 & $64 y+2 m$ & $64 y+2 m$ & $63 y+8 m$ & $62 y+2 m$ & $60 y+8 m$ & $59 y+2 m$ \\
\hline 1961 & $64 y+4 m$ & $64 y+4 m$ & $64 y+2 m$ & $62 y+8 m$ & $61 y+2 m$ & $59 y+8 m$ \\
\hline 1962 & $64 y+6 m$ & $64 y+6 m$ & $64 y+6 m$ & $63 y+2 m$ & $61 y+8 m$ & $60 y+2 m$ \\
\hline 1963 & $64 y+8 m$ & $64 y+8 m$ & $64 y+8 m$ & $63 y+8 m$ & $62 y+2 m$ & $60 y+8 m$ \\
\hline 1964 & $64 y+10 m$ & $64 y+10 m$ & $64 y+10 m$ & $64 y+2 m$ & $62 y+8 m$ & $61 y+2 m$ \\
\hline 1965 & $65 y$ & $65 y$ & $65 y$ & $64 y+8 m$ & $63 y+2 m$ & $61 y+8 m$ \\
\hline 1966 & $65 y$ & $65 y$ & $65 y$ & $65 y$ & $63 y+8 m$ & $62 y+2 m$ \\
\hline 1967 & $65 y$ & $65 y$ & $65 y$ & $65 y$ & $64 y+2 m$ & $62 y+8 m$ \\
\hline 1968 & $65 y$ & $65 y$ & $65 y$ & $65 y$ & $64 y+8 m$ & $63 y+2 m$ \\
\hline 1969 & $65 y$ & $65 y$ & $65 y$ & $65 y$ & $65 y$ & $63 y+8 m$ \\
\hline 1970 & $65 y$ & $65 y$ & $65 y$ & $65 y$ & $65 y$ & $64 y+2 m$ \\
\hline 1971 & $65 y$ & $65 y$ & $65 y$ & $65 y$ & $65 y$ & $64 y+8 m$ \\
\hline $1972+$ & $65 y$ & $65 y$ & $65 y$ & $65 y$ & $65 y$ & $65 y$ \\
\hline
\end{tabular}

Note: $\mathrm{y}$-years; $\mathrm{m}$ - months

Source: Act no. 203/2017 Coll., Act no. 155/1995 Coll. 
The question remains how to link the retirement age with the development of the life expectancy to achieve a certain degree of stabilisation of the average time of receipt of old-age pension. It would be natural to link the statutory retirement age not with the usual concept of biological ages characterizing the number of years lived, but with the concept of so-called prospective age taking into account the expected lengths of remaining life (Sanderson and Scherbov, 2007). The first proposals have appeared which, for example, envisaged selecting the retirement age in such a way that the average duration of the receipt of old-age pension would be roughly constant, say about 20 years. However, this would mean that, assuming a future increase in the length of life, the retirement age would grow and thus would the expected length of economic activity, but the time of receipt of a pension would remain the same and the relative time of receipt of the pension would decrease. The Expert Committee on Pension Reform therefore finally approved the recommendation that the value of the retirement age should be determined so that a person reaching senior age should receive an old-age pension on average for the last quarter of their lives (Expert Committee, 2015).

This recommendation has been accepted and, according to the current legislation, the Czech Statistical Office is obliged to publish a report on future demographic development every 5 years, containing calculations of the retirement age threshold so that people reaching senior age would receive an old-age pension on average for the last quarter of their lives. However, these calculations (concerning the period from 2030, i.e., cohorts born after 1965) will serve only an informative and advisory purpose, and it depends on Parliament whether the retirement age would be really raised in the proposed way (Act no. 203/2017 Coll.). Cohort life tables should be used for such calculations (Fiala and Langhamrová, 2015a). Results of the first such calculations were obtained at the end of 2018 (CZSO, 2018b).

This method of determination of the retirement age is based on a combination of both a backward-looking (remaining life expectancy) and a forward-looking (total life span) age measure. A possible indicator of such a type could be called relative remaining life expectancy defined as a proportion of the remaining life expectancy of the expected total life span

$$
r e_{x}^{(g)}=\frac{e_{x}^{(g)}}{x+e_{x}^{(g)}},
$$

where $r e_{x}^{(g)}$ denotes the relative life expectancy at the age $x$ of the birth cohort born in the year $g$. This indicator characterizes the length of remaining life not absolutely (the expected number of years left) but relatively (the expected proportion of life left). 
According to the proposal of the Pension Committee, the theoretical retirement age $x^{(g)}$ for the generation of those born in the year $g$ should be such that the relative life expectancy should be equal to 0.25 , i.e., the remaining life expectancy at the moment of reaching the retirement age should be equal to $1 / 3$ of the value of this age

$$
e_{x}^{(g)}=\frac{x}{3} .
$$

The retirement age threshold should be uniform for both males and females. The calculation of its value is based on unisex values of life expectancies equal to the average of corresponding values for males and females.

$$
e_{x}^{(g)}=\frac{e_{x}^{(g, M)}+e_{x}^{(g, F)}}{2}
$$

The average time of pension receipt for males would thus be about $24 \%$ of their life while for females it would be about 26\% (see Figure 3.).

Life expectancies are usually calculated for integer age values only. When seeking the value of retirement age, we therefore find from the life tables for the appropriate generation first of all the highest integer age value $x$ for which the above-mentioned share is still higher than or equal to 0.25 ; then we determine the "more accurate" value of retirement age by linear interpolation between values $x$ and $x+1$ where

$$
\frac{e_{x}^{(g)}}{x+e_{x}^{(g)}} \geq 0.25 \text { and } \frac{e_{x+1}^{(g)}}{x+1+e_{x+1}^{(g)}}<0.25 .
$$

With the exception of very low ages in populations having high infant and child mortality, where the so-called paradox of life expectancy occurs, life expectancy declines with increasing age and so the solution is always unequivocal.

This method of determination of the retirement age is similar to the idea of equitable normal pension age, where the ratio of the number of person-years lived from the pension age until death to the number of person-years lived from the age of 20 years until pension age should be stable over time and space for all population cohorts (Sanderson and Scherbov, 2014). Calculations of this pension age for Czech males (using the 2018 benchmark level) show slightly higher values of retirement age (Šídlo et al., 2020, p. 618, Table 2).

The values of retirement age which would guarantee old-age pension receipt for about the last quarter of the pensioner's life are shown in Figure 1 (dashed line). For cohorts born in the first decade of the previous century, the value would be very low - about 57 years only. The main reason was due to the fact, that these persons retired in the late 1950s or early 1960s, which marked the beginning of a long-term stagnation (and in some age 
groups even a temporary increase) of mortality rates of males; in the case of females, there was only a very slow decrease in mortality rates.

The retirement age threshold guaranteeing a pension for the last quarter of one's life was over 60 years of age only for cohorts born in the 1930s. People of these cohorts retired in the 1990s, i.e., at a time when life expectancy started to grow relatively rapidly again. It is remarkable that the value of the proposed retirement age guaranteeing a pension for the last quarter of the life span for the birth cohorts 1935-1965 is relatively close to the real value of retirement age of males of these cohorts. According to the latest population projection of the Czech population (CZSO, 2018a), the retirement age proposed in such a way should continue to rise for cohorts born after 1965 as well. Persons born in the present times (2020) should retire at the age of almost 68 years and 6 months (Figure 1).

Figure 1: Retirement age in Czechia

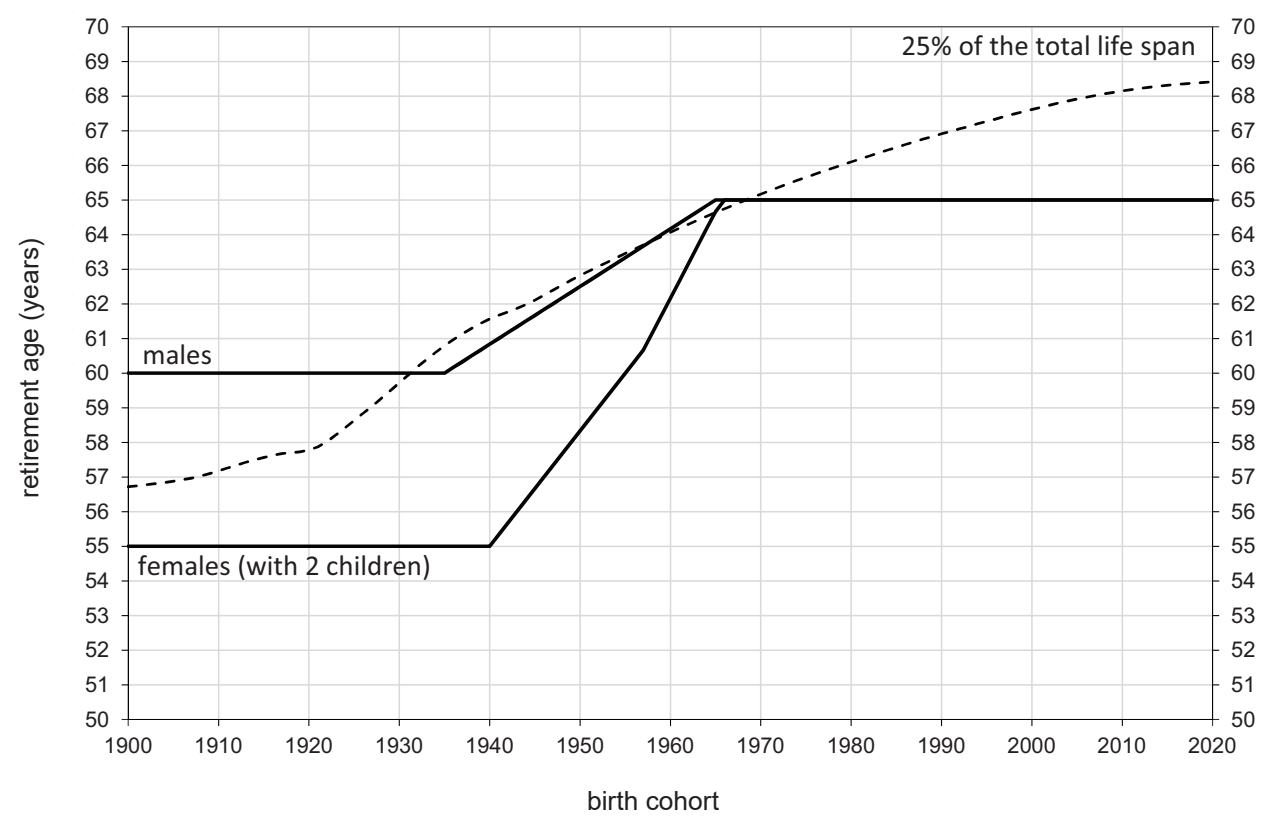

Note: solid line - present legislation; dashed line - retirement age guaranteeing pension receipt for $25 \%$ of the total life span (proposal of retirement age from 2031)

Source: Act no. 155/1995 Coll., Act no. 203/2017 Coll., authors' calculations and graph 


\section{Time of Pension Receipt}

The average time of pension receipt for males born in the first decade of the previous century (and so retiring in the 1960s) was relatively low - less than 15 years; for cohorts born in the second decade, it was a little over 15 years (Figure 2). It was roughly $20 \%$ of the total life span (Figure 3). More than $20 \%$ of adult males died before reaching retirement age (Figure 4); for cohorts born in the first years of the $20^{\text {th }}$ century, it was even more than $25 \%$. Almost a quarter of males received pension for no more than 10 years, about $30 \%$ for $10-20$ years. Only roughly $10 \%$ of males received a pension for longer than 25 years.

Females born in the same period (but retiring approximately 5 years earlier than males) received a pension for about 22-24 years, about $30 \%$ of their total life span. The proportion of females not surviving until retirement age was higher than $15 \%$ for the cohorts born in the first years of the $20^{\text {th }}$ century, but it decreased gradually below $10 \%$ for the cohorts born after 1917 . The proportion of females receiving a pension for less than 10 years was below $10 \%$. More than $1 / 3$ of females received a pension for $20-30$ years. The proportion of females receiving a pension for more than 30 years was lower than $20 \%$ for the first cohorts of the $20^{\text {th }}$ century, but it exceeds $25 \%$ for cohorts born after 1914 (Figure 5).

The time of pension receipt for cohorts born in the first two decades of the previous century increased only slightly especially for males due to the stagnation of mortality in Czechia in the 1960s, 1970s and early 1980s. The reasons for such a great difference between males' and females' time of pension receipt was not only the higher life expectancy of females but mainly the fact that females retired about 5 years earlier than males.

For cohorts of males born between 1920 and 1935 and of females born between 1920 and 1940, we observe a relatively rapid increase in the time of pension receipt. While the birth cohort of 1920 received a pension for only a little longer than 15 years on average ( $20 \%$ of the total life span), it was almost 18.5 years for the birth cohort of 1935 (23.5\% of the total life span). The proportion of adult males not surviving until pension age was still higher than $20 \%$; on the other hand, almost a quarter of males born in 1935 received a pension for $10-20$ years and even a little higher proportion for $20-30$ years. Over $10 \%$ of males received pension for more than 30 years.

The average time of pension receipt for females (with 2 children) rose from 24 years (birth cohort of 1920) to 28 years (birth cohort of 1940), i.e., from $30 \%$ to $34 \%$ of the total life span. The proportion of adult females dying before reaching pension age dropped below $6 \%$. In the birth cohort of 1940 , more than a quarter of adult females received a pension for 20-30 years and almost one half of females even for more than 30 years. 
The reason for such a rapid increase in the time of pension receipt was that these birth cohorts retired in the 1980s or 1990s, when life expectancy started to grow relatively rapidly while the retirement age remained unchanged - only 60 years for males and 55 years for females.

The time of old-age pension receipt for cohorts born after 1935 for males and after 1940 for females is considerably affected by the gradual increase of their retirement age to 65 years. For males (with an inter-cohort increase in retirement age by 2 months) of the birth cohorts 1936-1965 the (expected) time of pension receipt continued to grow (but very slowly) from 18.5 to 19.5 years, which is slightly higher than $23 \%$ of the total life span. The proportion of adult males not surviving until retirement age dropped under $20 \%$ for the cohorts born after the early 1950s. Almost one quarter of males should receive a pension for 10-20 years and the share of pensioners receiving a pension for 20-30 years should grow almost to one third. The proportion of males receiving a pension for more than 30 years should remain unchanged - slightly above $10 \%$. It is apparent that in the case of males, the increase in retirement age was fully compensated for by the decrease in mortality: it did not cut the time of pension receipt but it led to its relative stabilization.

For females (where the inter-cohort increment of retirement age was 4 months and since 2019 even 6 months), the time of pension receipt decreased remarkably. While for the cohort of 1940 (the latest cohort retiring at 55 years of age), the average time of pension receipt was about 28 years, the cohort of 1965 (retiring at 64 years and 8 months) will probably receive a pension only for about 23 years. The relative proportion will drop from $34 \%$ to $26 \%$ of the total life span. The proportion of adult females not surviving until retirement age will grow to almost $8 \%$. For the birth cohort of 1965 , more than $40 \%$ of females will receive a pension for $20-30$ years and the proportion of females receiving a pension for more than 30 years should drop to almost $20 \%$.

The average time of pension receipt of females born in 1965 (who will retire in 2030 at the age of 64 years and 8 months) is almost the same as for females born in 1911 (who retired in 1966 at the age of 55). However, there will be a remarkably higher proportion of females of the birth cohort of 1966 receiving a pension for 20-30 years and, on the other hand, a lower proportion of females not surviving until retirement age as well as a lower proportion of females receiving a pension for less than 20 years or for more than 30 years.

Because of the gradual unification of the retirement age for males and females, the gender gap between the average time of pension receipt should drop to roughly 3 years. Let us mention again that mortality in the older age of these cohorts is estimated by the mortality scenario of the medium variant of the population projection $(\mathrm{CZSO}$, 2018a). 
For the cohorts born after 1965, the time of pension receipt will depend substantially on the determination of the retirement age threshold. If (according to present legislation) it remains unchanged at the level of 65 years, the average time of pension receipt of males will grow gradually to more than 24 years (more than $27 \%$ of the total life span), for males born after 2010. The proportion of adult males not surviving until retirement age will drop to almost $7 \%$. About $44 \%$ of males born in 2020 will receive a pension for $20-30$ years and a quarter of males for even more than 30 years.

Females born in 2020 will receive a pension for more than 27 years $(29.5 \%$ of the total life span). The proportion of females of the birth cohort of 2020 not surviving until retirement age will be lower than $4 \%$. Almost $44 \%$ of females will receive a pension for 20-30 years and more than $38 \%$ will receive a pension for longer than 30 years.

If the retirement age for persons born after 1965 is determined according to the proposal that seniors should receive a pension on average for the last quarter of their lives and the development of mortality in Czechia follows the scenario of the medium variant of the projection of the Czech Statistical Office (CZSO, 2018a), the retirement age (uniform for males and females regardless of the number of their children) should grow gradually to almost 68.5 years for the birth cohort of 2020 (see Figure 1). The average time of pension receipt of males will rise very slowly to roughly 21.5 years (i.e., to $24 \%$ of the total life span) for the birth cohort of 2020. The proportion of males not surviving until pension age will drop below $10 \%$. More than $45 \%$ of males of this cohort will receive a pension for 20-30 years, the proportion of males receiving a pension for more than 30 years will remain stable - slightly over $11 \%$.

For females, the average time of pension receipt will grow to 24 years (i.e., to $26 \%$ of the total life span) for females born in 2020. The proportion of females not surviving until pension age will drop below 5\%. More than one half of females of this cohort will receive a pension for $20-30$ years, and almost $20 \%$ for more than 30 years.

An increase in the retirement age in such a way that people would receive a pension for the last quarter of their lives would stabilize the time of pension receipt relatively. The average time of pension receipt would grow very slowly. The proportion of people not surviving until pension age or receiving the pension for a relatively short time would continue the drop. On the other hand, the proportion of persons receiving a pension for a long time (more than 30 years) would remain stable or would even slightly decrease. 
Figure 2: Average time of old-age pension receipt

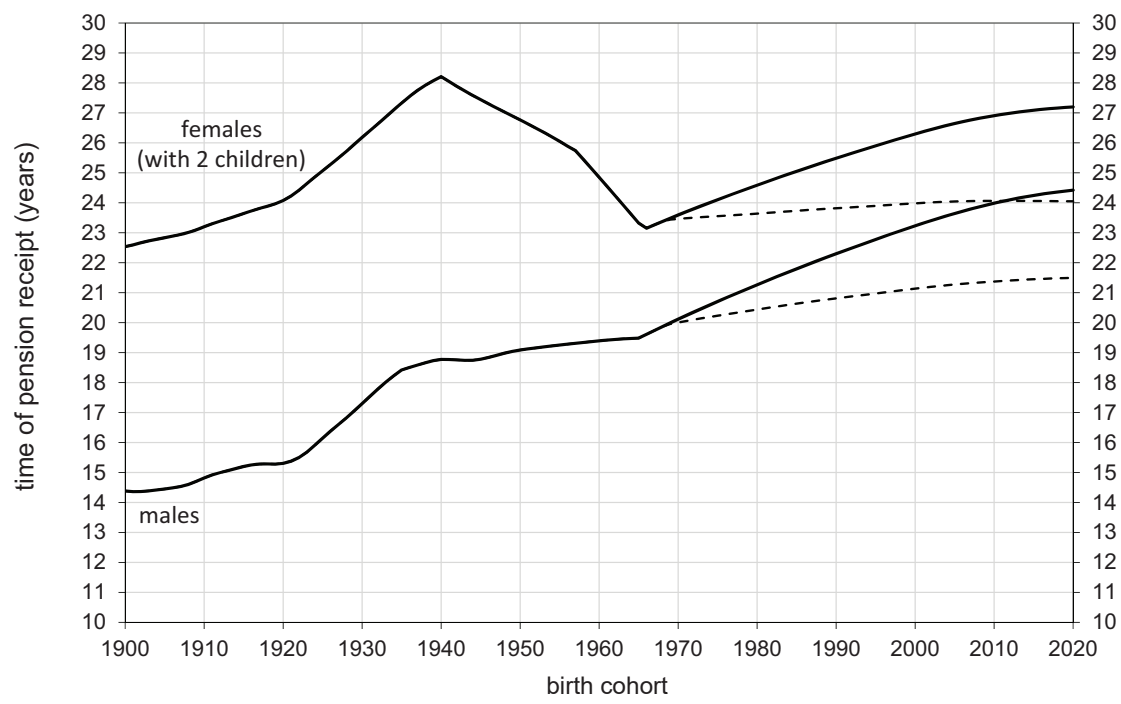

Note: solid line - present legislation (unchanged retirement age of 65 form 2031); dashed line - proposal (retirement age guaranteeing pension receipt for $25 \%$ of the total life span from 2031)

Source: Act no. 155/1995 Coll., Act no. 203/2017 Coll., authors' calculations and graph

\section{Figure 3: Relative average time of pension receipt (\% of the total life span)}

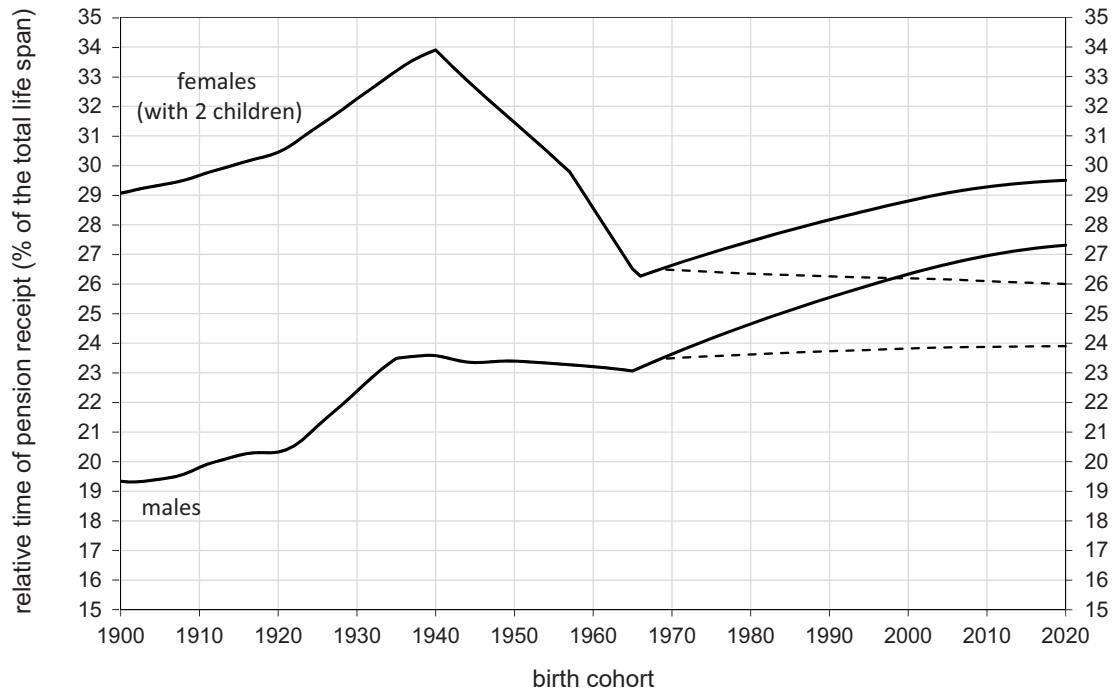

Note: solid line - present legislation (unchanged retirement age of 65 from 2031); dashed line - proposal (retirement age guaranteeing pension receipt for $25 \%$ of the total life span from 2031)

Source: Act no. 155/1995 Coll., authors' calculations and graph 


\section{Figure 4: Structure of estimated time of pension receipt, males}

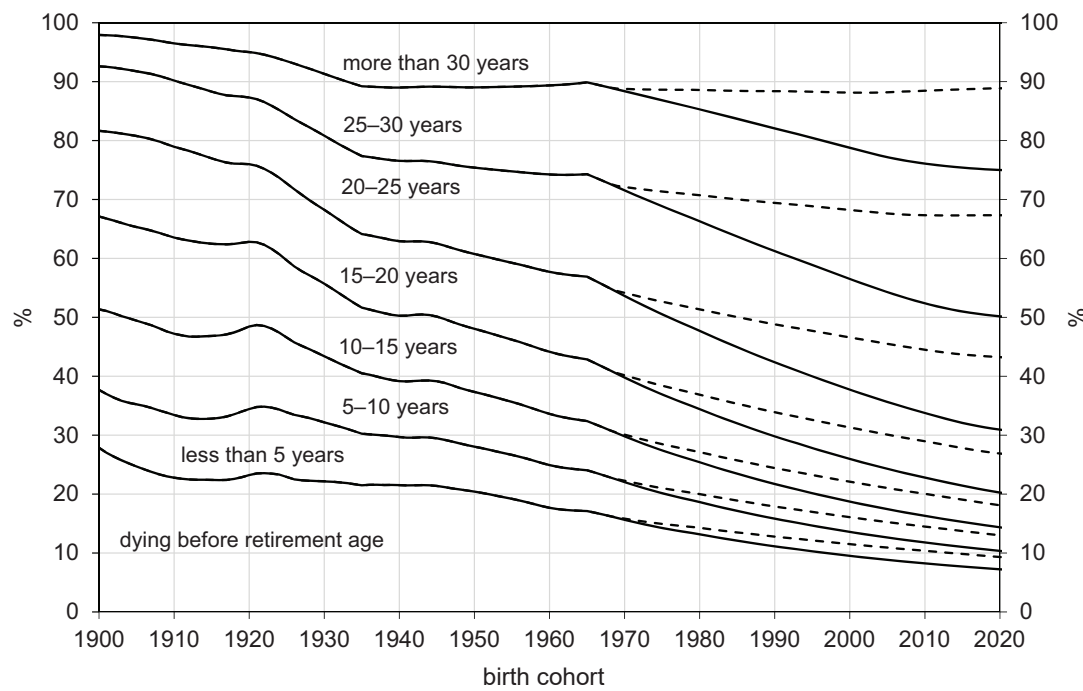

Note: solid line - present legislation (unchanged retirement age of 65 from 2031); dashed line - proposal (retirement age guaranteeing pension receipt for $25 \%$ of the total life span from 2031)

Source: Authors' calculations based on Czech Statistical Office data

\section{Figure 5: Structure of estimated time of pension receipt, females}

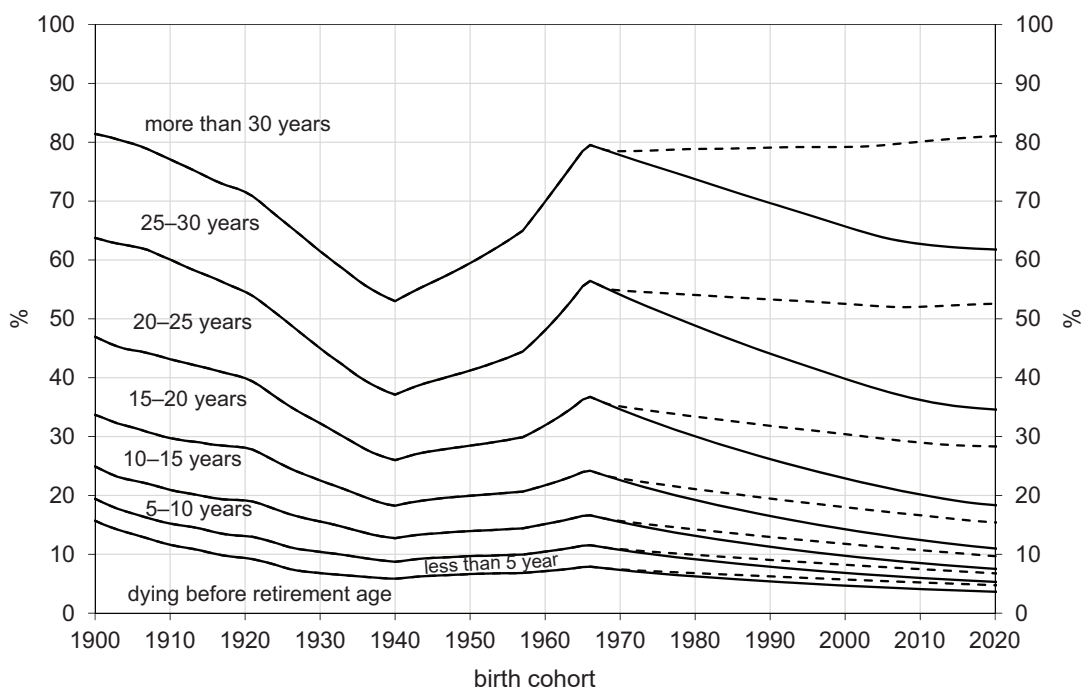

Note: solid line - present legislation (unchanged retirement age of 65 from 2031); dashed line - proposal (retirement age guaranteeing pension receipt for $25 \%$ of the total life span from 2031)

Source: Authors' calculations based on Czech Statistical Office data 


\section{Conclusion}

Increasing retirement age is a natural and logical measure for eliminating the consequences of population ageing for the financial sustainability of the Czech pension system. The retirement age in Czechia is still lower than in many other European countries; on the other hand, the life expectancy in Czechia is several years lower than in countries of Northern, Western and Southern Europe.

The increase in retirement age for males is fully compensated by the decrease in males' mortality. Younger cohorts affected by the increase in retirement age, nevertheless, have a slightly longer time of pension receipt than older cohorts retired at the age of 60 . The proportion of males not surviving until retirement age as well as of males receiving a pension for only a short time is decreasing.

In the case of females, the situation is quite different. The relatively rapid increase in retirement age intending to equalize the retirement age of females and males causes a decrease in the time of pension receipt for females born between 1941 and 1965. Nevertheless, the time of pension receipt is not lower than values for females born at the beginning of the previous century and retiring after WWII.

If the retirement age remains unchanged at the level of 65 years after 2030 (i.e., for persons born after 1965), it will result in a rapid increase of time of pension receipt. There will probably arise great problems of financing the pension system especially because of the fact that the numerous baby-boom cohorts born in the 1970s will retire gradually after 2040 .

The results of this study are of course valid under the assumption that the mortality rates since 2018 will follow the pattern of the scenario of the latest Czech population projection (CZSO, 2018a) - medium variant. In 2018 and 2019, life expectancy at birth for both males and females and life expectancy at the age of 65 for males were about 0.1 years lower than the scenario of the projection (CZSO, 2019a). Life tables for 2020 are not available yet but, according to preliminary estimates due to the Covid pandemic, the values of life expectancy at birth and at the age of 65 are expected to be about one year or even slightly more lower than the scenario values. If this unexpected development of mortality continues in the following years, the time of pension receipt will be (maybe remarkably) lower than the values presented in this paper. On the other hand, a slowdown or even stop of the decrease in mortality may cause the retirement age guaranteeing pension receipt for $25 \%$ of the total life span to be lower than 65 years.

The proposal to determine the retirement age in such a way that people should spend the last quarter of their total life span in pension on average would stabilize the time of pension receipt and so remarkably reduce the financial burden of the pension system. Of course, this would only apply if there were enough appropriate working opportunities for seniors over the age of 65 . 


\section{References}

Arltová, M., Langhamrová, J., Langhamrová, J. (2013). Development of Life Expectancy in the Czech Republic in Years 1920-2010 with an Outlook to 2050. Prague Economic Papers, 22(1), 125-143, https://doi.org/10.18267/j.pep.444

Burcin, B., Tesárková, K., Šídlo, L. (2010). Nejpoužívanější metody vyrovnávání a extrapolace křivky úmrtnosti a jejich aplikace na českou populace [The most frequent methods of smoothing and extrapolating mortality curves and their application to the Czech population]. Demografie, 52(2), 77-89.

CZSO (Czech Statistical Office) (2018a). Projekce obyvatelstva České republiky - 2018-2100. Tab. 6. Střední varianta bez migrace: Počet obyvatel podle věku (k 1. 1.) - muži. Tab. 7. Střední varianta bez migrace: Počet obyvatel podle věku (k 1. 1.) - ženy. Prague: Czech Statistical Office. Available at: https://www.czso.cz/csu/czso/ projekce-obyvatelstva-ceske-republiky-2018-2100

CZSO (Czech Statistical Office) (2018b). Přiloha ke Zprávě o očekávaném vývoji úmrtnosti, plodnosti a migrace $v$ České republice [An annex to the Report on the Expected Development of Mortality, Fertility and Migration in the Czech Republic]. Prague: Czech Statistical Office. Available at: https://www.czso.cz/documents/10180/94500304/zprava_priloha.xlsx/ ba090895-3067-4243-a511-7d186a9d93e1?version=1.0

CZSO (Czech Statistical Office) (2019a). Life Tables for the CR Since 1920. Prague: Czech Statistical Office. Available at: https://www.czso.cz/csu/czso/life_tables

CZSO (Czech Statistical Office) (2019b). Life Tables - Methodology. Prague: Czech Statistical Office. Available at: https://www.czso.cz/csu/czso/life-tables-methodology

Eilers, P. H. C., Marx, B. D. (1996). Flexible Smoothing with B-splines and Penalties. Statistical Science, 11(2), 89-121, https://doi.org/10.1214/ss/1038425655

European Council (2014). Council Recommendation of 8 July 2014 on the National Reform Programme 2014 of the Czech Republic and delivering a Council opinion on the Convergence Programme of the Czech Republic, 2014. Official Journal of the European Union (2014/C 247/03). Available at: http://eur-lex.europa.eu/ legal-content/EN/TXT/PDF/?uri=CELEX:32014H0729(03)\&from=CS

Expert Committee on Pension Reform Czech Republic (2015). Final Report on Activities in 2014. Expert Committee on Pension Reform Czech Republic. Available at: http://www.duchodova-komise.cz/wp-content/uploads/2015/02/Final-report-CoE-2014.pdf

Fiala, T., Langhamrová, J. (2015a). Computation of Retirement Age Based on Generation Life Tables, in 16th ASMDA Conference and Demographics 2015 Proceedings [online]. Piraeus, 30.06.2015 - 04.06.2015. Piraeus: University of Piraeus, pp. 199-208. ISBN 978-618-518005-8. Available at: http://www.asmda.es/images/1_E-G_ASMDA2015_Proceedings.pdf

Fiala, T., Langhamrová, J. (2015b). Hranice důchodového věku zajištující průměrnou dobu pobírání důchodu čtvrtiny života a modelové výpočty jeho hodnot [The threshold of retirement age guaranteeing the average time of receiving a pension for one quarter of life and model calculations of its values]. Fórum sociální politiky, 9(5), 2-8. 
Fuchs, V. R. (1984). Though Much is Taken: Reflections on Aging, Health, and Medical Care. The Milbank Memorial Fund Quarterly. Health and Society, 62(2), 143-166, https://doi.org/10.2307/3349821

Gavrilov, L. A., Heuveline, P. (2003). Aging of Population, in Demeny, P., McNicoll, G., eds., The Encyclopedia of Population. New York: Macmillan Reference USA.

Available at: http://onlinelibrary.wiley.com/doi/10.1111/j.1728-4457.2013.00633.x/full

Lee, R. D. (2000). The Lee-Carter Method for Forecasting Mortality, with Various Extensions and Applications. North American Actuarial Journal, 4(1), 80-91, https://doi.org/10.1080/ 10920277.2000.10595882

Lee, R. D., Carter, L. R. (1992). Modelling and Forecasting U.S. Mortality. Journal of the American Statistical Association, 87(419), 659-671, https://doi.org/10.2307/2290201

Pechholdová, M. (2019). Mortality Assumptions and Forecasting Methodology: Population Projection of the Czech Republic from the Czech Statistical Office, 2018-2100. Demografie, 61(4), 261-280.

Ryder, N. B. (1975). Notes on Stationary Populations. Population Index, 41(1), 3-28, https://doi.org/10.2307/2734140

Sanderson, W. C., Scherbov, S. (2005). Average Remaining Lifetimes Can Increase as Human Populations Age [online]. Nature, 435(7043), 811-813, https://doi.org/10.1038/ nature03593

Sanderson, W. C., Scherbov, S. (2010). Remeasuring Aging. Science, 329(5997), 1287-1288, https://doi.org/10.1126/science.1193647

Sanderson, W. C., Scherbov, S. (2013). The Characteristics Approach to the Measurement of Population Aging. Population and Development Review, 39(4), 673-685, https://doi.org/10.1111/j.1728-4457.2013.00633.x

Sanderson, W. C., Scherbov, S. (2014). An Easily Understood and Intergenerationally Equitable Normal Pension Age. International Institute for Applied Systems Analysis. Laxenburg Interim Report IR-14_020, 23 p. Available at: http://pure.iiasa.ac.at/id/eprint/11248/1/ IR-14-020.pdf

Siegel, J. S. (1993). A Generation of Change: a Profile of America's Older Population. New York: Russell Sage Foundation.

Šídlo, L., Šprocha, B., Ďurček, P. (2020a). A Retrospective and Prospective View of Current and Future Population Ageing in the European Union 28 Countries. Moravian Geographical Reports, 28(3), 187-207, https://doi.org/10.2478/mgr-2020-0014

Šídlo, L., Šprocha, B., Ďurček, P. (2020b). Prospective Dimension of Population Ageing and Potential Use in Pension Security in the V4 Countries. Ekonomický časopis, 68(6), 601-621.

Thatcher, R. A., Kanistö, V., Vaupel, J. W. (1998). The Force of Mortality at Ages 80 to 120. Odense University Press.

Zákon 155/1995 Sb., O důchodovém pojištění, aktuální znění, příloha. [Act no. 155/1995 of Coll., on pension insurance, as amended, an annex.] 
Zákon 203/2017 Sb., ze dne 8. června 2017, kterým se mění zákon č. 155/1995 Sb., o důchodovém pojištění, ve znění pozdějších předpisů, a některé další zákony. [Act no. 203/2017 of Coll. of 8 June 2017 amending Act no. 155/1995 of Coll, on pension insurance, as amended, and other laws.]

Zákon 220/2011 Sb., ze dne 21. června 2011, kterým se mění zákon č. 155/1995 Sb., o důchodovém pojištění, ve znění pozdějších předpisů, a některé další zákony. [Act no. 220/2011 of Coll. of 21 June 2011 amending Act no. 155/1995 of Coll, on pension insurance, as amended, and other laws.] 